\title{
Mengembangkan Kemandirian Belajar dalam Pembelajaran PPKn melalui Reward dan Punishment
}

\author{
Alinurdin $^{\mathrm{a}, 1 *}$, Suwahyu ${ }^{\mathrm{b}, 2}$ \\ a,bProgram Studi Pendidikan Pancasila dan Kewarganegaraan, \\ Fakultas Keguruan dan Ilmu Pendidikan, Universitas Pamulang, Tangerang Selatan

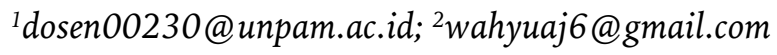 \\ *korespondensi penulis
}

Naskah diterima: 05-03-19, direvisi: 17-03-19, disetujui: 29-03-19

DOI: http://dx.doi.org/10.32493/jpkn.v6i1.y2019.p13-24

\begin{abstract}
Abstrak
Banyak guru tidak paham dengan apa yang dibutuhkan peserta didik, bahkan tidak mengerti cara memberikan motivasi. Padahal, terdapat berbagai cara yang bisa diterapkan guru dalam memotivasi peserta didik untuk mengembangkan kemandirian, salah satunya adalah dengan memberikan reward dan punishment. Penelitian ini bertujuan untuk melihat pengaruh pemberian reward dan punishment terhadap kemandirian belajar peserta didik dalam pembelajaran Pendidikan Pancasila dan Kewarganegaraan (PPKn). Penelitian menggunakan pendekatan kuantitatif dengan metode survei. Teknik pengambilan sampel yang digunakan adalah random sampling sederhana sebanyak 78 responden sebagai sampel. Hasil penelitian menunjukkan bahwa pemberian reward dan punishment berpengaruh positif dan signifikan terhadap kemandirian belajar peserta didik dalam pembelajaran PPKn. Para guru hendaknya melakukan pemberian reward dan punishment seperti pujian atau hadiah, teguran, tugas tambahan atau memberlakukan time out. Sehingga, secara tidak langsung memberikan pilihan kepada peserta didik untuk menentukan sikap mana yang harus mereka tampilkan.
\end{abstract}

Kata-kata kunci: kemandirian belajar; reward dan punishment; pembelajaran PPKn

\section{Abstract}

Many teachers do not understand what students need, even do not understand how to provide motivation. In fact, there are various ways that teachers can apply in motivating students to develop independence, one of which is to provide reward and punishment. This study aims to look at the effect of reward and punishment on the learning independence of students in learning Pancasila and Citizenship Education (PPKn). The study uses a quantitative approach with survey methods. The sampling technique used was simple random sampling of 78 respondents as samples. The results showed that the provision of reward and punishment had a positive and significant effect on the learning independence of students in learning PPKn. Teachers should provide rewards and punishments such as praise or gifts, reprimands, additional tasks or impose time-outs. So, it indirectly gives students choices to determine which attitudes they should display.

Keywords: independence of learning; reward and punishment; civics learning 
Jurnal Pendidikan Kewarganegaraan,

Vol. 4, No. 1, Maret 2017

\section{Pendahuluan}

Membentuk kemandirian peserta didik merupakan salah satu tujuan pendidikan nasional sebagaimana sebagaimana tercanyum dalam UU No. 20 Tahun 2003 tentang Sistem Pendidikan Nasional. Untuk menjadi manusia mandiri perlu dididik dan dibiasakan sejak dini dimulai pada lingkungan keluarga, kemudian di lingkungan pendidikan sekolah dan di masyarakat. Dalam lingkungan sekolah dimana seorang individu disebut sebagai peserta didik diharuskan menaati berbagai norma dalam keberlangsungan proses pendidikan. Di lingkungan inilah peserta didik akan diarahkan menjadi pribadi mandiri yang dimulai dari dalam kelas melalui proses pembelajaran. Kemandirian belajar menjadi hal yang perlu diperhatikan untuk mencapai tujuan pembelajaran. Kemandirian belajar memunculkan potensi bertanggung jawab, kemampuan memotivasi diri sendiri, berpikir kritis, dan mampu menjadi decision maker.

Membangun kerja sama antara guru dengan peserta didik penting guna memengaruhi motivasi belajar peserta didik selama berada di sekolah. Ketika guru dan peserta didik menjalin kerjasama yang positif dan suportif maka peserta didik akan memiliki dorongan yang lebih besar untuk belajar. Dalam memberikan motivasi, guru dapat melakukan berbagai cara
Available online at

http://openjournal.unpam.ac.id/index.php/PKn

salah satunya adalah dengan memberikan reward dan punishment.

Dalam penerapan pemberian reward sebaiknya diimbangi dengan punishment. Untuk membentuk kemandirian peserta didik, tidak hanya reward yang diberikan untuk meningkatkan kemauan belajar atau hanya pemberian punishment untuk memunculkan sikap disiplin. Keduanya perlu dimunculkan secara berdampingan agar terdapat option didalamya yang akan memacu peserta didik menentukan pilihan mereka sendiri apakah ingin mendapatkan reward atau justru membiarkan dirinya menerima punishment. Mampu menentukan pilihannya sendiri merupakan indikator kemandirian dalam belajar sehingga penerapan pemberian reward dan punishment sebagai motivasi untuk membentuk kemandirian belajar peserta didik.

Secara teori, reward dan punishment merupakan suatu bentuk motivasi yang biasa dilakukan oleh guru. Namun dalam beberapa penelitian ada juga yang dijadikan suatu metode pembelajaran lebih terperinci, maka dengan konsep-konsep tersebut dalam penelitian ini ingin memfokuskan pada teori reward dan punishment sebagai motivasi belajar.

Berdasarkan pengamatan awal peneliti kemandirian belajar belum merata pada seluruh peserta didik di SMP Negeri 6 Kota Tangerang Selatan khusunya pada kelas VII. Sikap yang masih ditemui berdasarkan 
pengamatan peneliti adalah kebiasaan yang selalu bergantung pada orang lain terutama bergantung pada temannya dalam mengerjakan tugas, masih ada peserta didik yang kurang mempersiapkan diri untuk mengikuti pembelajaran, sebagian peserta didik mempunyai buku panduan tetapi jarang dibaca, masih ada peserta didik yang mengandalkan guru sebagai sumber belajar utama sehingga tidak mencoba atau berinisiatif mencari sumber belajar lainnya. Secara umum hal diatas merupakan faktor-faktor yang menjadi penyebab kemandirian belajar peserta didik belum terbentuk dengan baik.

Guru di SMP Negeri 6 Kota Tangerang Selatan telah menerapkan pemberian reward dan punishment terutama guru PPKn juga telah memotivasi peserta didik dengan memberikan reward seperti memberikan pujian dan punishment seperti menegur peserta didik yang tidak disiplin. Sebagai bentuk motivasi belajar, Pemberian reward dan punishment harus dilakukan dengan tepat untuk menunjang pencapaian tujuan pembelajaran secara maksimal terutama dalam hal ini adalah kemandirian belajar. Pembelajaran merupakan suatu kegiatan interaksi antara pendidik, peserta didik dan komponen lainnya secara terarah dan sistematis guna mencapai tujuan tertentu. Pendidikan Pancasila dan Kewarganegaraan merupakan upaya untuk membentuk warga negara yang memiliki nilai-nilai dasar yang diyakini bangsa Indonesia sesuai yang diamanatkan dalam Pancasila.

Kemandirian sebagaimana diungkapkan Haris Mujiman (2007: 7) belajar adalah kegiatan belajar aktif, yang didorong oleh niat atau motif untuk menguasai sesuatu kompetensi guna mengatasi suatu masalah, dan dibangun dengan bekal pengetahuan atau kompetensi yang telah dimiliki. Sedangkan menurut Fahmi Irhamsyah, kemandirian belajar merupakan kesadaran diri untuk mengendalikan proses belajar dan bertanggung jawab sepenuhnya terhadap capaian hasil belajar. Kemandirian yang dimaksud bukan berarti seorang peserta didik belajar tanpa adanya guru, namun tentang bagaimana peserta didik bertanggung jawab ketika guru tersebut tidak ada atau ketika guru tersebut ada namun hanya berperan sebagai pengarah pembelajaran ,misalnya dalam model pembelajaran diskusi.

Dari beberapa pendapat tersebut maka dapat diambil kesimpulan bahwa kemandirian belajar adalah kegiatan belajar yang dilakukan oleh individu atas kesadaran dan kemauannya sendiri dan ditopang dengan penuh tanggung jawab. Selanjutnya hadiah (reward) menurut Slamento (2003: 176) adalah suatu bentuk pemeliharaan dan peningkatan motivasi siswa guna mendorong siswa untuk melakukan usaha lebih lanjut guna mencapai tujuan-tujuan pengajaran. Istilah lain 
reward adalah reinforcement yaitu merupakan dorongan bagi seseorang untuk bekerja dan belajar denngan giat. (Sardiman, 2007: 166). Pendapat Robert E. Slavin (2017: 187) mengemukakan bahwa hukuman merupakan konsekuensi yang tidak menyenangkan yang digunakan untuk melemahkan perilaku. Dari pengertian tersebut maka dapat ditarik kesimpulan bahwa Punishment atau hukuman merupakan suatu alat yang digunakan oleh guru untuk mengendalikan tingkah laku peserta didik agar sesuai dengan norma-norma yang berlaku dan sebagai upaya mencapai tujuan-tujuan pembelajaran secara efisien. Dari beberapa pendapat di atas maka dapat di simpulkan bahwa reward atau reinforcement adalah suatu cara yang dilakukan oleh guru untuk meningkatkan dorongan belajar dan memelihara konsistensi belajar dalam rangka pencapaian tujuan pembelajaran.

Pemberian reward dan punishment memberikan manfaat dalam proses pembelajaran karena keduanya mampu menjadi penggerak motivasi belajar dan juga sebagai alat pendidikan untuk mengendalikan tingkah laku peserta didik. Mendapatkan reward bagi peserta didik akan menghasilkan kesan yang menyenangkan sehingga peserta didik akan leih termotivasi untuk terus melakukannya bahkan meningkatkan perbuatan agar mendapatkan reward dan ini akan membawa pengaruh kepada peserta didik lain ketika temannya mendapatkan reward atas perbuatannya, mereka terpacu untuk melakukannya pula. Sebaliknya punishment menghasilkan kesan tidak menyenangkan bagi peserta didik yang mendapatkannya, sehingga peserta didik pun akan berusaha untuk tidak melakukan perbuatan yang sama.

Pemberian reward dan punishment hendaknya dilakukan secara berdampingan artinya seorang guru tidak hanya memberikan reward atas perbuatan baik peserta didik tetapi juga harus memberikan punishment bagi peserta didik yang kurang disiplin. Misalnya guru memberikan tugas kepada peserta didik ketika ada peserta didik yang mengerjakan tugas dengan baik maka guru dapat memberikan reward berupa pujian, apresiasi, atau lainnnya dan bagi peserta didik yang tidak mengerjakan tugas diberikan punishment sebagai bagian dari proses perbaikan diri peserta didik dan guru juga dapat memberikan teguran atau tanbahan tugas kepada peserta didik tersebut.

Dalam hukum pengaruh "The Law of Effect" Thorndike sebagaimana dikutip oleh Ratna Wilis Dahar (2011: 19) mengemukakan bahwa jika suatu tindakan diikuti oleh suatu perubahan yang memuaskan dalam lingkungan kemungkinan tindakan itu diulangi dalam situasi yang mirip akan meningkat. Akan tetapi, bila suatu perilaku diikuti oleh suatu perubahan 
yang tidak memuaskan dalam lingkungan, kemungkinan perilaku itu akan menurun. Jadi, konsekuensi perilaku seseorang pada suatu waktu memegang peranan penting dalam menentukan perilaku orang itu selanjutnya.

Dari pendapat tersebut terlihat bahwa reward dan punishment merupakan satu kesatuan konsep yang saling mempengaruhi. Ketika pemberian reward diimbangi dengan pemberian punishment maka akan menimbulkan suatu efek khusus kepada peserta didik. Peserta didik dapat menentukan sikap untuk melakukan tindakan yang menghadirkan reward atau tindakan yang dapat menghadirkan punishment, yang pasti ketika peserta didik mampu menentukan pilihannya sendiri artinya peserta didik sudah berani mengambil resiko yang didalamnya terdapat tanggung jawab yang harus dilaksanakan. Entah itu tanggung jawab untuk menerima segala konsekuensi apabila dia memilih sikap yang menghadirkan punishment atau tanggung jawab untuk mempertahankan pencapaian reward, justru upaya mempertahankan pencapian itu lebih sulit dibandingkan proses meraihnya. Jadi yang dimaksud dengan reward dan punishment merupakan suatu bentuk motivasi belajar yang dapat mendorong peserta didik untuk belajar secara aktif dan partisipatif. Sedangkan kemandirian belajar sebagai salah satu tujuan pendidikan nasional diperlukan sebagai upaya pembentukan individu yang bertanggung jawab dan memiliki kemampuan dalam proses penyesuaian diri.

Pemberian reward dan punishment memiliki peranan yang penting dalam proses pembelajaran karena reward dan punishment merupakan bentuk motivasi belajar peserta didik yang berasal dari faktor luar atau eksternal yang dapat mempengaruhi kemandirian belajar peserta didik. Reward dan punishment terdiri dari berbagai bentuk, bukan hanya memberikan hadiah yang bersifat materil seperti makanan, barang dan uang dan bukan juga hanya memberikan hukuman berupa kontak fisik seperti memukul atau memarahi, akan tetapi reward dan punishment ternyata memiliki berbagai bentuk. Dengan memberikan ucapan penyemangat, menyampaikan kalimat memotivasi dan memberi teguran yang membangun, itu merupakan beberapa bentuk lainnya dari reward dan punishment yang dapat membangkitkan motivasi belajar yang berasal dari luar diri peserta didik.

Reward dapat memberikan pengalaman yang menimbulkan kesan menyenangkan sedangkan punishement memberikan pengalaman yang menimbulkan kesan yang tidak menyenangkan. Perbedaan inilah menjadi suatu option. Dengan adanya hal tersebut peserta didik dapat 
memilih pengalaman mana yang mereka inginkan dengan begitu peserta didik mampu menentukan pilihannya sendiri serta bertanggung jawab atas pilihannya itu. Sedangkan mampu menentukan pilihannnya sendiri dan bertanggung jawab merupakan beberapa indikator kemandirian.

Mandiri merupakan salah satu tujuan pendidikan nasional yang diupayakan perwujudannya melalui kegiatan pembelajaran. Kemandirian belajar akan lebih mudah dibiasakan oleh peserta didik melalui peran guru untuk menggerakkan motivasi belajar dengan salah satu cara yaitu memberikan reward dan punishment sehingga peserta didik akan semakin giat dan semangat belajar secara mandiri.

\section{Metode}

Metode dalam penelitian ini adalah metode survei melalui pendekatan kuantitatif dengan bentuk penelitian korelasi. Penelitian ini untuk mengetahui adakah pengaruh pemberian reward dan punishment terhadap kemandirian belajar peserta didik dalam pembelajaran PPKn SMP Negeri 6 Kota Tangerang Selatan. Teknik pengambilan sampel dalam penelitian ini menggunakan random sampling sederhana pada peserta didik kelas VII sejumlah 336 peserta didik sebagai populasi terjangkau, kemudian jumlah sampel ditentukan dengan rumus slovin sehingga hasil yang didapat adalah 78 peserta didik sebagai responden. Instrumen yang dipakai dalam penelitian ini yaitu menggunakan angket dalam bentuk skala likert, baik untuk variabel pemberian reward dan punishment (X) maupun kemandirian belajar (Y). Masing-masing variabel terdiri atas 30 butir pernyataan dengan 5 alternatif jawaban diantaranya Sangat Setuju, Setuju, Kurang Setuju, Tidak Setuju, dan Sangat Tidak Setuju.

\section{Hasil dan Pembahasan}

\section{Pemberian Reward dan Punishment}

Teknik mengambilan data menggunakan kuesioner berupa skala Likert, jawaban kuisioner tersebut kemudian diolah dengan memberikan skor sesuai dengan tabel skor jawaban kuisioner yang telah ditentukan. Selanjutnya pemberian skor data tersebut dikembangkan dalam bentuk tabel distribusi frekuensi dengan perhitungan sebagai berikut : banyak data $(\mathrm{n})=78$, data tertinggi adalah 120 dan data terendah diperoleh 79 , entang $(\mathrm{R})=41$, banyak kelas $=7$, dan panjang kelas $=6$

Berdasarkan data tersebut, maka dapat dibuat tabel daftar distribusi variabel $X$ sebagai berikut. 
Tabel 1. Daftar Distribusi Variabel

\begin{tabular}{|c|c|c|c|c|c|c|c|c|c|c|c|c|}
\hline NO & & terv: & & $\begin{array}{c}\text { Tepi } \\
\text { bawah }\end{array}$ & $\begin{array}{l}\text { Tepi } \\
\text { atas }\end{array}$ & $\begin{array}{c}\text { Tanda } \\
\text { Kelas } \\
\text { (Xi) }\end{array}$ & $\begin{array}{c}\text { Absolu } \\
\mathbf{t} \\
(\mathbf{F i}) / \mathbf{F o}\end{array}$ & KUM & FiXi & $\mathbf{X i - x i}$ & $(\mathbf{X i}-\mathbf{x i})^{2}$ & $\begin{array}{c}\mathbf{F i}(\mathbf{X i}- \\
\mathbf{x i})^{\mathbf{2}}\end{array}$ \\
\hline 1 & 79 & - & 85 & 78,5 & 85,5 & 82 & 10 & 10 & 820 & $-17,230$ & 296,899 & 2968,99 \\
\hline 2 & 86 & - & 92 & 85,5 & 92,5 & 89 & 11 & 21 & 979 & $-10,230$ & 104,668 & 1151,3 \\
\hline 3 & 93 & - & 99 & 92,5 & 99,5 & 96 & 16 & 37 & 1536 & $-3,2307$ & 10,4378 & 167,005 \\
\hline 4 & 100 & - & 106 & 99,5 & 106,5 & 103 & 23 & 60 & 2369 & 3,76923 & 14,2071 & 326,763 \\
\hline 5 & 107 & - & 113 & 106,5 & 113,5 & 110 & 10 & 70 & 1100 & 10,7692 & 115,976 & 1159,76 \\
\hline 6 & 114 & - & 120 & 113,5 & 120,5 & 117 & 8 & 78 & 936 & 17,7692 & 315,745 & 2525,96 \\
\hline$\Sigma$ & & & & & & 597 & 78 & & 7740 & 1,61538 & 857,934 & 8299,8 \\
\hline
\end{tabular}

Berdasarkan tabel frekuensi distribusi tersebut diperoleh rentang nilai sebesar 41 dengan skor tertinggi 120 dan skor terendah 79, banyak kelas 7, dengan panjang interval 6. Kemudian masingmasing kelas interval dapat digambarkan dengan grafik histogram sebagai berikut.

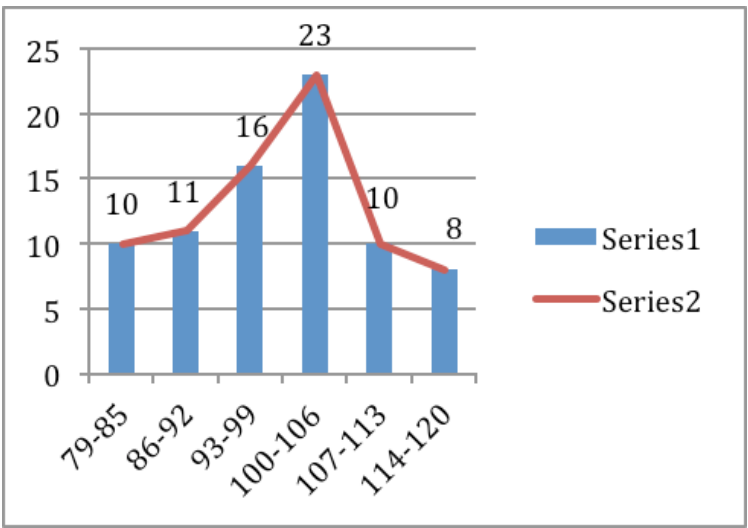

Berdasarkan deskripsi di atas terlihat bahwa frekuensi tertinggi pemberian reward dan punishment peserta didik SMP Negeri 6 Kota Tangerang Selatan Kelas VII, terletak antara 100-106 dengan frekuensi relatif 23 peserta didik. diperoleh pula nilai rata-rata (mean) sebesar 99.23 nilai tengah (median) sebesar 100,11 dan nilai modus sebesar 101,95. Perolehan nilai kuiartil 1 adalah 91,52, nilai kuartil 2 adalah 100,11, perolehan nilai kuartil 3 sebesar 106,01, nilai desil adalah 98,51 , perolehan nilai persentil sebesar 96,11, perolehan nilai simpangan baku sebesar 10.4 dan simpangan (varian) sebesar 107,79.

\section{Kemandirian Belajar}

Jawaban dari kuesioner kemandirian belajar (variable Y) yang telah didapat tersebut kemudian diolah dengan

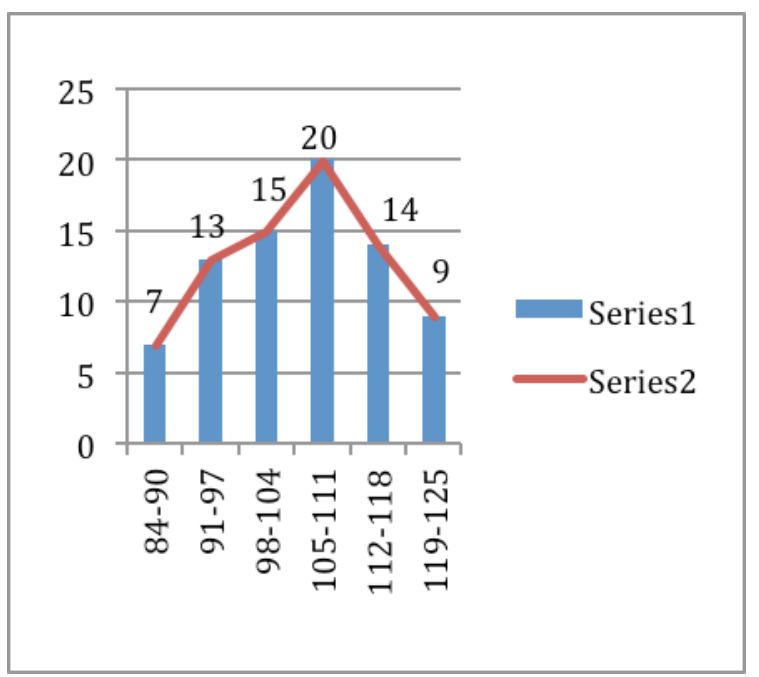




\begin{tabular}{|c|c|c|c|c|c|c|c|c|c|c|c|c|}
\hline $\begin{array}{l}\mathbf{N} \\
\mathbf{O}\end{array}$ & & Interv & & $\begin{array}{c}\text { Tepi } \\
\text { bawa } \\
\text { h }\end{array}$ & $\begin{array}{l}\text { Tepi } \\
\text { atas }\end{array}$ & $\begin{array}{c}\text { Tanda } \\
\text { kelas } \\
\text { (Xi) }\end{array}$ & $\begin{array}{l}\text { Abs } \\
\text { olut } \\
\text { (Fi) } \\
\text { /Fo }\end{array}$ & KUM & FiXi & $\mathbf{X i - x i}$ & $(\mathrm{Xi}-\mathbf{x i})^{2}$ & $F i(X i-x i)^{2}$ \\
\hline 1 & 84 & - & 90 & 83,5 & 90,5 & 87 & 7 & 7 & 609 & $-18,3077$ & 335,171 & 2346,20 \\
\hline 2 & 91 & - & 97 & 90,5 & 97,5 & 94 & 13 & 20 & 1222 & $-11,3077$ & 127,863 & 1662,23 \\
\hline 3 & 98 & - & 104 & 97,5 & 104,5 & 101 & 15 & 35 & 1515 & $-4,30769$ & 18,5562 & 278,343 \\
\hline 4 & $\begin{array}{c}10 \\
5\end{array}$ & - & 111 & 104,5 & 111,5 & 108 & 20 & 55 & 2160 & 2,69230 & 7,24852 & 144,970 \\
\hline 5 & $\begin{array}{c}11 \\
2\end{array}$ & - & 118 & 111,5 & 118,5 & 115 & 14 & 69 & 1610 & 9,69230 & 93,9408 & 1315,17 \\
\hline 6 & $\begin{array}{c}11 \\
9\end{array}$ & - & 125 & 118,5 & 125,5 & 122 & 9 & 78 & 1098 & 16,6923 & 278,633 & 2507,69 \\
\hline$\Sigma$ & & & & & & 627 & 78 & & 8214 & $-4,84615$ & 861,414 & 8254,61 \\
\hline
\end{tabular}

memberikan skor sesuai dengan tabel skor jawaban kuisioner yang telah ditentukan. Selanjutnya pemberian skor data tersebut dikembangkan dalam bentuk tabel distribusi frekuensi dengan perhitungan sebagai berikut: banyaknya data $(\mathrm{n})=78$, data tertinggi 125 dan data terendah diperoleh 84 , rentang $(\mathrm{R})=7$, panjang kelas Interval $(P)=6$

Berdasarkan data tersebut, maka dapat dibuat daftar distribusi frekuensi variabel $\mathrm{Y}$ sebagai berikut. Dari tabel frekuensi distribusi tersebut diperoleh rentang nilai sebesar 41 dengan skor tertinggi 125 dan skor terendah 84, banyak kelas 7, dengan panjang interval 6 . Kemudian masing-masing kelas interval dapat digambarkan dengan grafik histogram sebagai berikut.

105-111 dengan frekuensi relatif 20 peserta didik. diperoleh pula nilai ratarata (mean) sebesar 105,31 nilai tengah (median) sebesar 105,9 dan nilai modus sebesar 107,7. Perolehan nilai kuiartil 1 adalah 97,22, nilai kuartil 2 adalah 105,9., perolehan nilai kuartil 3 sebesar 112,55, nilai desil adalah 108,63, perolehan nilai persentil sebesar 105,9, perolehan nilai simpangan baku sebesar 10,3 dan simpangan (varian) sebesar 107,2 .

Berdasarkan analisis data dengan menggunakan metode statistik maka dapat dideskripsikan hasil penelitian pada hipotesis penelitian yaitu terdapat pengaruh positif dan signifikan antara pemberian reward dan punishment terhadap kemandirian belajar peserta didik dalam pembelajaran PPKn kelas VII di SMP Negeri 6 Kota Tangerang Selatan. Oleh karena hal tersebut dapat dinyatakan bahwa pemberian reward dan punishment mempengaruhi kemandirian belajar peserta didik, artinya peserta didik yang diberikan reward dan punishment dapat memiliki tingkat kemandirian belajar yang cukup baik dan sebaliknya peserta didik yang tidak mendapatkan reward dan punishment kurang memiliki kemandirian belajar yang baik. Hal ini juga didukung oleh penelitian Aswandi yang telah dilakukan sebelumnya dengan judul Pemberian Reward Terbaik Tiap Bulan Terhadap Kedisiplinan Peserta Didik, yang 
menunjukkan pengaruhnya sebesar $46 \%$ sedangkan $54 \%$ dipengaruhi dari faktor lain. Demikian pula penelitian Tati Haryanti pada tahun 2015 dengan judul Disiplin Belajar dalam Pendidikan Pancasila dan Kewarganegaraan Terhadap Sikap Mandiri Peserta Didik telah membuktikan pengaruh sebesar $25,31 \%$ sedangkan $74,69 \%$ dipengaruhi dari faktor lain.

Penyebaran angket dilakukan kepada 78 peserta didik di kelas VII SMP Negeri 6 Kota Tangerang Selatan yang dijadikan sebagai responden. Instrumen penletian yang digunakan dalam proses pengumpulan data adalah angket dalam bentuk skala Likert, terdiri dari 30 butir pernyataan tiap variabel dan semua butir pernyataan valid. Data hasil angket pemberian reward dan punishment menghasilkan rata-rata 99,23. Nilai yang tertinggi 120 dan nilai terendah 79 serta angket kemandirian belajar menghasilkan rata-rata 105,31 dengan nilai tertinggi 125 dan terendah 84 . Sesuai dengan koefisien determinasi sebesar $28,85 \%$, artinya pemberian reward dan punishment berpengaruh sebesar 28,85\% terhadap kemandirian belajar peserta didik sedangkan 71,15 \% lainnya dipengaruhi oleh faktor lain.

Setelah dilakukan pengujian hipotesis dengan hipotesis Ho : $F_{\text {hitung }}>F_{\text {tabel, }}$ maka tidak berpengaruh positif atau $(\mathrm{Y} \neq \mathrm{bX})$, atau Ho: $\mathrm{F}_{\text {hitung }}<\mathrm{F}_{\text {tabel }}$ maka berpengaruh positif $(\mathrm{Y}=\mathrm{a}+\mathrm{bX})$. Hasil yang diperoleh dari pengujiaan $\mathrm{Y}=\mathrm{a}+\mathrm{bX}$ adalah 50,996 $+0,554 \mathrm{X}$ dengan uji linieritas $\mathrm{F}_{\text {hitung }}$ sebesar -1,108 sementara $F_{\text {tabel }}$ sebesar 1,518 sehingga dapat disimpulkan bahwa
$\mathrm{F}_{\text {hitung }}<\mathrm{F}_{\text {tabel }}$ maka variabel pemberian reward dan punsihment terbukti berpengaruh positif terhadap variabel kemandirian belajar.

Setelah melihat hasil uji hipotesis menggunakan Uji Anava One Way dengan kriteria keputusan $\mathrm{F}_{\text {hitung }}>\mathrm{F}_{\text {tabel }}$ yang berarti signifikan. Hasil yang diperoleh uji hipotesis adalah $F_{\text {hitung }}$ sebesar 30,82 dengan $F_{\text {tabel }}$ sebesar 2,772 yang berarti $\mathrm{F}_{\text {hitung }}>\mathrm{F}_{\text {tabel }}$ terbukti variabel pemberian reward dan punishment berpengaruh positif dan signifikan terhadap kemandirian belajar peserta didik. Hasil Uji hipotesis dengan Uji korelasi Product Moment Menunjukkan bahwa $t_{\text {hitung }}=5,55>t_{\text {tabel }}=0,1852$ yang artinya atas pemaparan tersebut maka dapat disimpulkan bahwa hipotesis diterima. Karena Hipotesis yang dikemukakan dalam penelitian ini terdapat pengaruh yang positif dan signifikan antara pemberian reward dan punsihment terhadap kemandirian belajar peserta didik dalam pembelajaran PPKn Kelas VII di SMP Negeri 6 Kota Tangerang Selatan Tahun Pelajaran 2018/2019.

\section{Kesimpulan}

Berdasarkan hasil penelitian dapat disimpulkan bahwa terdapat pengaruh yang positif dan signifikan antara pemberian reward dan punishment terhadap kemandirian belajar peserta didik dalam pembelajaran PPKn di SMP Negeri 6 Kota Tangerang Selatan pada kelas VII. Sesuai dengan koefisien determinasi (KD) sebesar 28,85\%, artinya pemberian reward dan punishment berpengaruh sebesar 28,85 \% terhadap kemandirian 
belajar peserta didik, sedangkan 71,15\% lainnya dipengaruhi oleh faktor lain. Hasil pengujian hipotesis dimana $t_{\text {hitung }}>t_{\text {tabel }}$ atau 5,55 > 0,1852. Dengan demikian Ho ditolak dan Ha diterima. Jadi, dinyatakan bahwa pemeberian reward dan punishment berpengaruh positif dan signifikan terhadap kemandirian belajar.

Atas dasar hal tersebut, maka perlu memunculkan suatu upaya dari pihak yang berkepentingan baik itu pihak sekolah, para guru dan peserta didik itu sendiri agar lebih memperhatikan penerapan atau pemberian reward dan punishment

Penelitian ini telah membuktikan bahwa terdapat pengaruh positif dan signifikan antara pemberian reward dan punishment terhadap kemandirian belajar peserta didik. Maka peneulis mencoba memberikan saran yang dapat digunakan sebagai referensi atau pertimbangan dalam upaya meningkatkan kemandirian belajar peserta didik.

Peserta didik hendaknya lebih meningkatkan kemandirian dalam berbagai aktivitas khususnya kemandirian dalam belajar. Mandiri menjadi salah satu tujuan pendidikan nasional sebagai potensi yang perlu dikembangkan oleh karena hal tersebut kemandirian menjadi sangat penting bagi peserta didik. Guru dan lembaga pendidikan formal berusaha dengan keras untuk memebentuk kemandirian belajar peserta didik namun apabila peserta didik itu sendiri menutup diri maka tentu upaya untuk meningkatkan kemandirian belajar juga akan cukup sulit. Sehingga kiranya peserta didik mau membuka diri untuk belajar dan terus belajar menjadi pribadi yang lebih baik.

Dalam upaya mencapai tujuan pendidikan nasional tentu perlu dukungan dari berbagai pihak terutama peran guru sangat penting. Dalam peningkatan kemandirian belajar peserta didik hendaknya guru perlu melakukan beberapa cara salah satu yang dapat diterapkan adalah pemberian reward dan punishment. Pemberian pujian atau hadiah merupakan bentuk reward atas sikap atau perilaku yang dilakukan secara baik dan disiplin. Punishment dijadikan rekan pengimbang reward bagi peserta didik yang kurang disiplin, dengan begitu secara tidak langsung memberikan pilihan kepada peserta didik untuk menentukan sikap mana yang harus mereka tampilkan.

Hasil dari penelitian ini mampu dijadikan sebagai bahan rujukan guna melakukan penelitian selanjutnya serta diharapkan dapat lebih disempurnakan dengan adanya perbaikan pada beberapa kekurangan yang ada dalam penelitian ini, sehingga hasil yang diperoleh bisa lebih baik.

\section{Referensi}

Sardiman, A. M. (2007). Interaksi dan Motivasi Belajar Mengajar. Jakarta: PT Raja Grafindo Persada.

Dahar, R. W. (2011). Teori-teori Belajar dan Mengajar.Jakarta: Erlangga.

Dalyono, M. (2005). Psikologi Pendidikan. Jakarta: PT Asdi Mahasatya.

Darmadi, H. (2014). Urgensi Pendidikan Pancasila dan Kewarganegaraan di Perguruan Tinggi.Bandung: Alfabeta. 
Jurnal Pendidikan Kewarganegaraan

Vol. 6 No. 1 Maret 2019

Irhamsyah, F. dkk. (2016). Pendidikan 18 Karakter Bangsa: Kreatif dan Mandiri. Jakarta: Mustika Pustaka Negeri.

Kaelan. (2014). Pendidikan Pancasila. Yogyakarta: Paradigma.

Mujiman, H. (2007). Belajar Mandiri. Surakarta: UNS Press.

Purwanto, N. (2007). Ilmu Pendidikan Teoretis dan Praktis. Bandung: PT. Remaja Rosdakarya.

Slameto. (2010). Belajar dan Faktor-faktor yang Mempengaruhinya. Jakarta: Rineka Cipta.
Journal of Civics and Education Studies p-ISSN 2302-0865 | e-ISSN 2621-346X

Slavin, R. E. (2017). Psikologi Pendidikan: Teori dan Praktik Jilid 1. Jakarta: PT Indeks.

Sunarto, B. \& Hartono, A. (2006). Perkembangan Peserta Didik. Jakarta: PT Rineka Cipta.

Yusuf, S. A. \& Nurihsan, J. (2011). Teori Kepribadian. Bandung: PT Remaja Rosdakarya. 
Jurnal Pendidikan Kewarganegaraan

Vol. 6 No. 1 Maret 2019
Journal of Civics and Education Studies p-ISSN 2302-0865 | e-ISSN 2621-346X

[ halaman ini sengaja dikosongkan ] 